\title{
Autobusem i tramwajem w przeszłość. Berlińskie zaszłości w twórczości Annett Gröschner
}

\begin{abstract}
Pytel-Bartnik Ewa, Autobusem i tramwajem w przeszłość. Berlińskie zaszłości w twórczości Annett Gröschner [By bus and by train into the past. Berlin and its legacy in Annett Gröschner's writing]. „Przestrzenie Teorii” 24, Poznań 2015, Adam Mickiewicz University Press, pp. 125-143. ISBN 978-83-232-2982-7. ISSN 1644-6763. DOI 10.14746/ pt.2015.24.7.

This paper concentrates on the strategies of reconstructing the past as inscribed into the urban space of Berlin and discussed within the literary field. Developed by the German writer Annett Gröschner, they have been used to reexamine the history of the city - only dimly reflected in the present urban landscape. Her perspective emphasizes the distinctive spatial and architectural organization of the city, particularly after the fall of the Berlin Wall. In order to harness her dialectical composition of the spacing-of-the-past, Gröschner uses the map of various routes on the Berlin public transport network, some inner-city artefacts set along those lines, and also the city map with its constant modifications to create appropriate landmarks through which she [re]constructs Berlin's past-present.
\end{abstract}

Przestrzeń miejska Berlina - jego architektura i topografia - służą niemieckim pisarzom, szczególnie po 1989 roku, jako kulisy dla refleksji nad historią Niemiec w XX i XXI wieku oraz przekształceniami społeczno-politycznymi i kulturowymi, które pociągnęły za sobą symboliczne działania urbanizacyjne i architektoniczne w tym mieście, wywołując spory o przeszłość i pamięć o niej, a także o formy jej upamiętniania ${ }^{1}$. Wczesne narracje miejskie ${ }^{2}$ powstałe po 1989 roku do końca lat 90 . XX

${ }^{1} \mathrm{O}$ sporze o pamięć zakorzenioną w tkance miejskiej Berlina i roli miejskich artefaktów w budowaniu tożsamości jego mieszkańców pisze Aleida Assmann w: A. Assmann, Geschichte im Gedächtnis. Von der individuellen Erfahrung zur öffentlichen Inszenierung, München 2007, szczególnie s. 110-135. Ciekawe spojrzenie na konflikt między pamięcią indywidualną i kolektywną, wynikającą z rewolucji przestrzennej w Berlinie po przełomie 1989/1990, prezentuje również M. Saryusz-Wolska w artykule Strategie pamięci zbiorowej $w$ przestrzeni miejskiej. Problemy Berlina po zjednoczeniu Niemiec, [w:] Przemiany pamięci społecznej a teoria kultury, red. B. Korzeniewski, Poznań 2007, s. 131-150. Zajmuję się tym zagadnieniem m.in. w: E. Pytel-Bartnik, Monika Marons Geburtsort Berlin (2003) - Die Stadt als Archiv der Erinnerung, [w:] Das »Prinzip Erinnerung" in der deutschsprachigen Gegenwartsliteratur nach 1989, red. C. Gansel, P. Zimniak, Göttingen 2010, s. 179-190.

2 Zurbanizowana przestrzeń Berlina, pokazana jako ogromny plac budowy, była dla niemieckich autorów wschodniej i zachodniej proweniencji w okresie przełomu 1989/1990 i transformacji częstym tłem do rozważań nad przezwyciężeniem trwającego pół wieku 
wieku wpisały się w trend, który Susanne Ledanff nazwała „metropolizacją literatury”3. Późniejsza literatura miejska z Berlinem w roli głównej wyraźnie inkorporowała zainteresowanie przestrzenią w naukach humanistycznych w ramach dyskursu pamięci (Jan i Aleida Assmann) ${ }^{4}$ oraz $\mathrm{w}$ zwrotach - przestrzennym i topograficznym ${ }^{5}$ i w geopoetyce ${ }^{6}$. Tak jest również w przypadku twórczości berlińskiej autorki Annett Gröschner (ur. 1964), osadzonej w historii Berlina ukazanego jako centrum ideologii oraz eksperymentalny plac zniszczeń i budowy w rękach kolejnych przywódców politycznych ${ }^{7}$. Tempo i totalny charakter przełomu urbanizacyjnego $\mathrm{w}$ zjednoczonym Berlinie nieprzerwanie angażują pamięć o mieście, w którym w szczególności budynki powstałe za czasów NRD ustępują zamiennikom architektonicznym, co czyni nieodległą jeszcze historię trudno rozpoznawalną lub nawet nieczytelną we współczesnym krajobrazie miasta. Assmann tak komentuje „rewolucję przestrzenną"8 w Berlinie po 1989 roku: „Po fazie abstynencji od tradycji, patosu, godności i historii Berlin chce wiele nadrobić, ale dzieje się to z taką werwą, która kryje w sobie niebezpieczeństwo zakopania przy okazji niedawnej historii, tzn. byłej stolicy NRD”9. Ten bliski Berlinowi stan istnienia w sensualnym

podziału oraz nad integracją obu społeczeństw niemieckich. Stała się tym samym alegorią ich kondycji - młodego społeczeństwa w budowie. Widać to w utworach np.: P. Schneider, Eduards Heimkehr, Berlin 1999; J. Sparschuha, Der Zimmerspringbrunnen, Köln 1995; T. Dückers, Spielzone, Berlin 1999.

3 Zob. S. Ledanff, Metropolisierung der deutschen Literatur? Welche Möglichkeiten eröffnet das vereinigte Berlin und die Berliner Urbanität?, [w:] Schreiben nach der Wende. Ein Jahrzehnt deutscher Literatur 1989-1999, red. G. Fischer, D. Roberts, Tübingen 2001, s. 275-289.

${ }^{4}$ Kultur und Gedächtnis, red. J. Assmann, T. Hölscher, Frankfurt a. Main 1988; J. Assmann, Pamięć kulturowa. Pismo, zapamiętywanie i polityczna tożsamość w cywilizacjach starożytnych, przeł. A. Kryczyńska-Pham, Warszawa 2008.

${ }_{5}^{5}$ Zwrot przestrzenny i topograficzny dyskutowany był obszernie w Niemczech $\mathrm{np}$. w: J. Döring, T. Thielmann, Spatial Turn. Das Raumparadigma in den Kultur- und Sozialwissenschaften, Bielefeld 2008; D. Bachmann-Medick, Cultural Turns. Neuorientierungen in den Kulturwissenschaften, Reinbek bei Hamburg 2010; Topologie. Zur Raumbeschreibung in den Kultur- und Medienwissenschaften, red. S. Günzel, Bielefeld 2007.

${ }^{6}$ E. Rybicka, Geopoetyka. Przestrzeń i miejsce we wspótczesnych teoriach i praktykach literackich, Kraków 2014; Geopoetiken, red. M. Marszałek, S. Sasse, Berlin 2010.

7 Zagadnieniu mnemotycznej funkcji architektury w Berlinie poświęciłam uwagę w tekście: E. Pytel-Bartnik, Architektura i pamięć. Przypadek Berlina w powieści Annett Gröschner 'Walpurgistag', [w:] Miasto 5. Przestrzeń zróżnicowana językowo, kulturowo $i$ społecznie, red. M. Święcicka, Bydgoszcz 2014, s. 313-326.

$8 \mathrm{~K}$. Schlögel, W przestrzeni czas czytamy. O historii cywilizacji $i$ geopolityce, przeł. I. Drozdowska, Ł. Musiał, Poznań 2009, s. 23.

9 A. Assmann, Geschichte findet Stadt, [w:] Kommunikation - Gedächtnis - Raum. Kulturwissenschaften nach dem »Spatial Turn«, red. M. Csăky, Ch. Leitgeb, Bielefeld 
nieistnieniu Maria Popczyk nazwała, czytając pragmatykę estetyczną Richarda Shustermana, „miastem widzialnej nieobecności”10. Nieobecność i pustka w miejscu zburzonej architektury i niepamięć o minionym sprawiają, że Berlin jest wielowymiarową kompozycją znaczeń, kreacją pamięci zbiorowej i indywidualnej oraz produktem imaginacji. Ewa Rewers celnie podsumowuje tę semantykę pustki w Berlinie: „Tutaj, to, co niewidzialne, przenika widzialne, nienazwane pozostaje w nazwach, zabudowane otacza puste, a pustka budynki"11. Twórczość Gröschner jest literackim komentarzem do symbolicznych metamorfoz architektonicznych $\mathrm{w}$ Berlinie $\mathrm{z}$ okresu transformacji i czasu postzjednoczeniowych przemian, odsłaniającym wielowarstwową historię obecną $\mathrm{w}$ jego przestrzeni miejskiej. W niniejszym artykule proponuję rozpoznanie strategii rekonstrukcji przeszłości, po jakie sięga Gröschner, aby przypomnieć historię Berlina słabo zauważalną w krajobrazie miejskim. Omówię wybrane eseje miejskie autorki z tomiku Hier beginnt die Zukunft, hier steigen wir aus. Unterwegs in der Berliner Verkehrsgesellschaft ${ }^{12}$ (2002, Tu rozpoczyna sie przyszłość. Tu wysiadamy. Podróże berlińska komunikacja miej$s k a)$. Odniosę się także do pokrewnych tematycznie zbiorów - Parzelle Paradies (2008, Parcela Raj)13 i Heimatkunde Berlin ${ }^{14}$ (2010, Berlin. Wiadomości krajoznawcze). W analizie kulturoznawczo-literaturoznawczej odwołam się do modelu pisania historii miastem (urbane Geschichtsschreibung) Waltera Benjamina, opartego na koncepcji uprzestrzennienia przeszłości ${ }^{15}$ oraz na jego dialektycznej wizji historii16. Także figura flaneura jest $\mathrm{w}$ niniejszym artykule kluczem do zrozumienia omawianych relacji przestrzenno-pamięciowych, bowiem w Hier beginnt die $\mathrm{Zu}$ kunft pisarka łączy pracę uważnego spacerowicza i obserwatora zmieniającego się krajobrazu miasta z wysiłkiem historyka i archeologa, by „od-

2009, s. 13-27, tu: 25-26. Wszystkie tłumaczenia, o ile nie podano inaczej, pochodzą od Autorki artykułu.

10 M. Popczyk, Berlin - miasto widzialnej nieobecności, [w:] Dylematy wielokulturowości, red. W. Kalaga, Kraków 2004, s. 239-261.

11 E. Rewers, Post-polis. Wstęp do filozofii ponowoczesnego miasta, Kraków 2005, s. 50 .

12 A. Gröschner, Hier beginnt die Zukunft, hier steigen wir aus. Unterwegs in der Berliner Verkehrsgesellschaft, Berlin 2002.

13 Taż, Parzelle Paradies, Hamburg 2008.

14 Taż, Heimatkunde Berlin, Hamburg 2010.

15 W. Benjamin, Passagenwerk, [w:] Walter Benjamin, Gesammelte Schriften, Bd. V. 2., red. R. Tiedemann, Frankfurt am Main 1982, s. 1041.

${ }_{16}$ Zob. tenże, O pojęciu historii, [w:] tegoż, Anioł historii. Eseje, szkice, fragmenty, wybór i oprac. H. Orłowski, przeł. K. Krzemieniowa, H. Orłowski, J. Sikorski, Poznańska Biblioteka Niemiecka, t. 2., Poznań 1996, s. 418. 
kopać"17 historię Berlina i uczynić ją widoczną dla świata18. Praktyce patrzenia towarzyszy więc analiza historyka tropiącego konteksty ${ }^{19}$, by opowiedzieć historię Niemiec przestrzenią Berlina. W tym ujęciu widać praktykę „archeomonadologiczną"20, która zbliża pisarkę do Benjaminowskiego patrzenia na historię i pamięć zakorzenioną w zurbanizowanej przestrzeni miasta. Dialektyczność tej metody polega na odkrywaniu kolejnych warstw miejskiej tkanki historycznej, a następnie składaniu rozbitych elementów historii $\mathrm{w}$ obraz przeszłości i pamięci ${ }^{21}$. W omawianiu miejskich esejów berlińskiej pisarki towarzyszy mi również koncepcja przestrzenno-pamięciowa Aleidy Assmann, która wyróżnia miejsca jako „areny historycznych wydarzeń, jako form[ę] kondensacji i materializacji historii, jako nośniki znaków i śladów, które ulegają zniszczeniu lub są przechowywane, odrzucane lub rozszyfrowane, wyróżnione lub zakwestionowane, zapomniane lub przypomniane"22. Impresje miejskie Gröschner czytam także przez pryzmat rozważań Karla Schlögla, dla którego miasto jest tekstem pełnym znaków i symbolicznych znaczeń, w którym zmaterializowała się historyczna przeszłość. Schlögel zauważa:

Kontakt z jakimkolwiek miastem stanowi coś w rodzaju czytania od końca skamieniałości. Wiemy, że to koralowiec, który ma swoją historię, który tylko wydaje się zastygły, skamieniały, jakby uszło z niego życie, jednak nadal można domyśleć się po jego wyglądzie spełnianej funkcji ${ }^{23}$.

\section{Związki przestrzenno-historyczno-pamięciowe}

Przestrzeń i czas, historia i pamięć są w utworach berlińskiej pisarki silnie ze sobą związane. Ilustracją tych relacji jest grafika na stronie internetowej autorki, przypominająca schemat linii komunikacji miejskiej (zob. rycinę) 24 . Na spersonalizowanej mapie, którą tworzy pięć linii komunikacyjnych zamiast nazw przystanków odnaleźć można tytuły utwo-

17 W. Benjamin, Berliner Chronik, [w:] Walter Benjamin - Gesammelte Schriften, Bd. VI: Fragmente, Autobiographische Schriften, red. R. Schweppenhäuser, W. Tiedemann, Frankfurt am Main 1984, s. 486.

18 Zob. W. Benjamin, Ausgraben und Erinnern, [w:] tegoż, Gesammelte Schriften, IV. 1, red. T. Rexroth, Frankfurt am Main 1972, s. 400-401.

${ }^{19}$ K. Schlögel, dz. cyt., s. 270.

${ }^{20}$ Zob. J. Kusiak, Walter Benjamin i metodologia antropologicznego materializmu. Krzesanie dialektycznych iskier na metalowej gtowie Ernsta Thälmanna, „Praktyka Teoretyczna" 2013, nr 2(8), s. 309-332, tu: s. 312.

${ }^{21}$ Zob. W. Benjamin, O pojęciu historii..., s. 418.

${ }^{22}$ A. Assmann, Geschichte findet Stadt ..., s. 9.

${ }^{23}$ K. Schlögel, dz. cyt., s. 301.

$24<\mathrm{http} / / / \mathrm{www}$.annettgroeschner.de/annett-groeschner/>, dostęp: 1.12.2015. 
rów, m.in. Moskauer Eis ${ }^{25}$, Walpurgistagen, Parzelle Paradies, Gleimstraße ${ }^{27}$, Heimatkunde Berlin czy omawiany tu cykl esejów Hier beginnt die Zukunft, hier steigen wir aus. Tytuły dzieł pisarki odnoszą się do konkretnych miejsc na planie miasta, usytuowanych głównie w dzielnicach Mitte i Prenzlauer Berg, należących niegdyś do Berlina Wschodniego. Nie byłoby tych opowieści bez miejsc, które można odszukać na planie miasta, bez ulic, parków, budynków, ruin sklepowych, bez linii tramwajowych, autobusowych i linii S-Bahn, bez przystanków i dworców, bez zakorzenienia $\mathrm{w}$ konkretnej topografiii ${ }^{28}$. Wspomniane tu poetyki przestrzenne Annett Gröschner nie powstałyby także, gdyby nie determinacja autorki w poszukiwaniu śladów przeszłości Berlina i wypełnianiu pustek architektonicznych - brakujących elementów palimpsestowej układanki miejskiej - wiedzą o nieobecnym, znalezioną w archiwach i bibliotekach, a także opartą na własnym doświadczeniu miasta i przeniesioną z tradycji literackiej, z dzieł Waltera Benjamina, Franza Hessela i Siegfrieda Kracauera. To utwory napisane przeciw zapomnieniu, przywracające znaczenie miejscom, ożywiające je dzięki pracy odpominania autora-obserwatora-narratora i poruszeniu pamięci czytelnika, który podróżuje $\mathrm{z}$ narratorem $\mathrm{w}$ historycznej przestrzeni Berlina trasami środków komunikacji miejskiej i współtworzy tę przestrzeń pamięci.

W szkicach miejskich Hier beginnt die Zukunft Gröschner przejmuje Benjaminowski model uprzestrzennionej historii („die raumgewordene Vergangenheit")29. Niemal każdy element zabudowy architektonicznej Berlina jest w esejach formą zapisu czasu w przestrzeni, a ona - tożsama $\mathrm{z}$ narratorem - poruszająca się w niej, niczym flaneur odczytuje ślady i szczątki przeszłości, ożywia ruiny i przywraca im pamięć. Trudno w utworach Gröschner o miejsca neutralne historycznie, nienaznaczone przeszłością̧ ${ }^{30}$ Przeważają historyczne hybrydy, ale autorka potrafi rów-

25 A. Gröschner, Moskauer Eis..., Berlin 2009.

26 Taż, Walpurgistag. Roman, Berlin 2011.

27 Taż, Grenzgänger. Wunderheiler. Pflastersteine. Die Geschichte der Gleimstraße in Berlin, Reinbek bei Hamburg 1998.

${ }^{28}$ Elżbieta Rybicka w rozważaniach nad bliskością nauk humanistycznych i geografii podkreśla, że przestrzeń geograficzna we współczesnych praktykach literackich i artystycznych nie funkcjonuje jako neutralne tło, ale jako siła sprawcza tworząca kulturę. Por. E. Rybicka, dz. cyt., s. 140. W tym aspekcie utwory Gröschner inspirowane przestrzenią miejską Berlina można odczytać jako teksty kultury z jednej strony, z drugiej jako narracje wpisujące się w kulturę pamięci.

${ }^{29}$ W. Benjamin, Passagenwerk..., s. 1041.

30 Model historyczno-przestrzennej narracji prezentuje Gröschner np. w powieści Walpurgistag (Dzień Walpurgi), w której bohaterowie poruszają się po współczesnym planie miasta, a ich kroki, wzorem Benjaminowskiego flaneura, rezonują przeszłość. W mie- 
nież docenić mnemotyczną wartość topografii spoza kanonu miejsc pamięci, lieux de memoire (Pierre Nora), znajdujących się poza szlakiem atrakcji turystycznych. Narrację w Hier beginnt die Zukunft uzupełniają fragmenty rozmów pasażerów, czy to w dialekcie berlińskim, czy w żargonie młodzieżowym, a także, w niektórych miniaturach, fragmenty Spazieren in Berlin Hessela. Tak powstały kolaż narracyjny sprawia, że obraz Berlina wyłaniający się ze „spacero-podróży” autorki jest wielogłosową kompozycją, symulującą rzeczywistość i wyobrażeniem opartym na własnej interpretacji krajobrazu miejskiego, a także impresji literackich autorów referencyjnych. „Rzeczywiste” obrazy miasta mieszają się w esejach Gröschner z imaginariami, przestrzeniami wyobrażonymi. Paradoksalnie, to imaginacja czyni je silniej obecnymi we współczesnej tkance miejskiej, z której wymazała ją współczesność. Rolf Lindner podkreśla zalety imaginacji w procesie poznawczym:

Wyobrażone nie jest opozycją względem rzeczywistego, ani też jego odbiciem, a innym, poetycko-obrazowym sposobem kontaktu z tym, co realne. Wyobrażone potęguje znaczenie i zagęszcza przedmiot wyobrażenia (miasto, miejsce), tak, że jesteśmy w stanie widzieć jaśniej, ostrzej i głębiej ${ }^{31}$.

Imaginariom należy więc przypisać funkcję intensyfikatorów pamięci. Ta konkluzja będzie przydatna w analizie estetyzacji współczesnego obrazu Berlina, jaką znajdujemy w twórczości Gröschner.

\section{Spacero-przejażdżki}

Dla Annett Gröschner, urodzonej w 1964 roku we wschodnioniemieckim Magdeburgu, Berlin Wschodni, do którego przyjechała w 1983 roku na studia, stał się stacją docelową, punktem orientacyjnym, a także, ze względu na obecność muru, platformą widokową na jego zachodnią część. Odnajdywała ją w planie miasta jako „biał[ą] powierzchni[ę] z zielonymi plamami i szerokimi bezimiennymi magistralami”32. Młoda Gröschner zastała ulice Berlina przeraźliwie szare i opustoszałe, „rolety na parterze domów spuszczone”33. Autorka następująco opisuje kondycję społeczeń-

ście wszechobecna jest historia, która domaga się odkrycia i opowiedzenia właśnie w spersonalizowanej historii bohaterów.

${ }^{31}$ R. Lindner, Textur, imaginaire. Habitus - Schlüsselbegriffe der kulturanalytischen Stadtforschung, [w:] Die Eigenlogik der Städte. Neue Wege für die Stadtforschung, red. H. Berking, M. Löw, Frankfurt a.M. 2008, s. 83-94, tu s. 87.

32 Zob. A. Gröschner, Heimatkunde Berlin..., s. 8.

33 Tamże, s. 10. Podobny obraz społeczeństwa wschodnioniemieckiego lat 80. - w apatii, głębokiej frustracji i deziluzji - rysuje wymownie Christoph Hein w noweli Der fremde Freund - Obcy przyjaciel, przeł. B. Tarnas, Warszawa 1985. 
stwa wschodnioniemieckiego lat 80.: „Trafiłam do społeczeństwa w bezruchu, nazwać ten stan schyłkiem, to byłoby już zbyt wiele ruchu, pisarka Elke Erb nazwała to kompleksowo ogarniającą stagnacją" ${ }^{4}$. Azylem od opresyjnego systemu stały się dla Gröschner knajpy. Tylko tam socjalizm wydawał jej się znośny. Autorka tłumiła alkoholem ostre doświadczenie enerdowskiej codzienności ${ }^{35}$. Trwałą ulgę przyniosła jej jednak dopiero ucieczka „do kraju niczyjego pomiędzy wierszami”36 - w pisarstwo. Z jednej strony pisanie, z drugiej bliskość miasta i tłumu, spacer oraz przejażdżka tramwajem i autobusem po wschodniej części miasta pozwoliły Gröschner przetrwać świadomość podziału Niemiec, jakiego doświadczała do 1989 roku i którego ślady dokumentuje współcześnie. Zbiór esejów miejskich Hier beginnt die Zukunft, hier steigen wir aus to subiektywny dziennik ze spacero-podróży po Berlinie lat dziewięćdziesiątych, oparty na koncepcji flanerii, ale jest to podróż środkami komunikacji miejskiej, przerywana spacerami, wzdłuż czterech linii tramwajowych, trzynastu autobusowych, jednej linii promem i jednej linii nocnego autobusu. Dla Gröschner flaneria po Berlinie możliwa jest jedynie komunikacją miejską ${ }^{37}$. Historię stolicy Niemiec autorka opowiada przede wszystkim przez pryzmat zmian na mapie linii środków komunikacji miejskiej, a także na planie miasta, będących następstwem przełomów polityczno-społecznych w tym kraju w XX wieku. W porzadkowaniu, systematyzowaniu ogromu przeszłości, jaki skrywa niemal każda ulica, każdy zakątek miasta, i przeniesieniu jej do świata linearnej narracji pomogła pisarce właśnie mapa linii komunikacji miejskiej i plan miasta. Gęsty, wielowarstwowy historycznie obraz Berlina, jaki autorka rysuje w swoich utworach, jest efektem obserwacji poczynionych przez nia „na powierzchni" - podczas spacerów i przejażdżek autobusem i tramwajem - oraz podczas zejścia „w głąb miasta”, do niewidzialnych warstw jego dziejów. Pisarka spędziła ponad dwa lata „na powierzchni” i wiele lat w bibliotekach i archiwach, by dotrzeć do rozproszonych elementów uprzestrzennionej historii, częściowo już niewidocznej i nierozpoznawalnej w przestrzeni miejskiej Berlina, i złożyć je w całość. Gröschner wyznaczyła sobie ambitne zadanie, by prozą uchwycić zmieniający się pejzaż miejski. Strategię tropienia śladów przeszłości w ruchu wyjaśnia następująco:

Jeździć autobusem i tramwajem, znaczy patrzeć na powierzchnię miasta. Mija się miejsca, nie mogąc zajrzeć w głąb. Sens tworzy się dopiero w ciągu obrazów.

\footnotetext{
${ }^{34}$ A. Gröschner, Heimatkunde Berlin..., s. 10.

35 Tamże, s. 10.

36 Tamże, s. 14.

37 Taż, Parzelle Paradies..., s. 8.
} 
Spojrzeć przez okno, rozejrzeć się w środku, czasem przyjrzeć się wnętrzu człowieka, które się uzewnętrzniło. Poza tym w Berlinie nawet na powierzchni dają się jeszcze wyraźnie zauważyć występki historii. Trzeba tylko przyjrzeć się dwa razy. [...] Często przejeżdża się obojętnie obok budynków, których historii nie da się odczytać jedynie z fasad, a która ujawnia się dopiero, kiedy zagląda się za kulisy ${ }^{38}$.

Każdy esej jest relacją z przejażdżki-spaceru wzdłuż konkretnej linii komunikacyjnej, a jego tytuł łączy dwie czasoprzestrzenie: przeszłą i teraźniejszą topografię, dawny i dzisiejszy Berlin. Oto przykładowy tytuł: „Przez most Bornholmski można jechać tramwajem na zachód. Linią tramwajową 23 przez północno-wschodnie dzielnice do Mitte, która nazywała się kiedyś Wedding"39. Po zachodniej części Berlina pisarka nieprzypadkowo podróżuje autobusami ${ }^{40}$. Historia zamknięcia linii tramwajowych w tej części miasta sięga 1954 roku. W ostatni kurs po tej stronie muru tramwaj wyjechał w 1967 roku. Można więc uznać, że mapa linii tramwajowych i autobusowych w Berlinie odzwierciedlała geopolityczny porządek, tzn. odmienną politykę rozwoju miasta, w tym tę dotyczącą komunikacji miejskiej. I choć autobusy i tramwaje od 1992 roku kursują w Berlinie ${ }^{41}$ pod zjednoczonym niebem, zarządzane przez jedno miejskie przedsiębiorstwo komunikacyjne BVG (Berliner Verkehrsgesellschaft), Gröschner dziesięć lat po zjednoczeniu wychwytuje subtelny, ale jednak symptomatyczny podział miasta na część wschodnią i zachodnią, widoczny choćby w preferencjach czytelniczych kierowców berlińskich środków komunikacji publicznej. We wschodnim Berlinie w tramwajach czyta się Berliner Kurier, a w autobusach po zachodniej stronie miasta - Berliner Zeitung42. W Hier beginnt die Zukunft autorka nie ogranicza się do porównań dawnych i aktualnych tras środków komunikacji miejskiej i wyliczenia obiektów architektonicznych widzianych przez okno tramwaju lub autobusu, lecz uzupełnia swoją narrację o szkic historyczny, kulturowy i obyczajowy. Wyjaśnia, że o wyborze konkretnej linii komunikacyjnej przesądził fakt, że linia ta „przekracza niewidzialne społeczne, kulturowe, a także polityczne granice”, które widoczne były sto lat wcześniej

${ }^{38}$ Taż, Hier beginnt die Zukunft..., s. $13 \mathrm{f}$.

39 Tamże, s. 135. Na moście Bornholmskim znajdowało się przejście graniczne, tu tramwaj kończył swoją trasę.

40 Istnieją w Berlinie jedyne dwie linie tramwajowe łączące wschodnią z zachodnią częścią miasta - linia M 13 otwarta w 1995 i M 10 w 2006 roku. Zob. <www.bvg.de/index. php/de/3746/name/MetroTramlinie+M13.html>, dostęp: 4.08.2014.

$41 \mathrm{~W} 1992$ połączyły się wschodnio- i zachodnioniemieckie przedsiębiorstwo komunikacji publicznej.

${ }^{42}$ A. Gröschner, Hier beginnt die Zukunft..., s. 140. 
i utrzymują się do dziśs ${ }^{4}$. Środki komunikacji miejskiej to dla berlińskiej autorki zróżnicowana kulturowo przestrzeń, a ich pasażerowie stanowią przekrój społeczeństwa. Autobus i tramwaj to centra komunikacji międzyludzkiej, które funkcjonują, zauważa Gröschner, jak „przedłużenie pokoju" 44 (Verlängerung des Zimmers), na co wskazują wplecione w eseje podsłuchane treści rozmów. I tak współczesność/codzienność przeplata się w Hier beginnt die Zukunft z przeszłością/historycznością, w którą pasażerowie nieświadomie wkraczają, podróżując berlińską komunikacją miejską.

\section{Zapomniane szyny i mur}

Młoda Gröschner przypadkiem odkrywa zalety zmechanizowanej flanerii, wsiadając w 1983 roku do niewłaściwego tramwaju w obcym jej jeszcze Berlinie, który obserwuje z ciekawością ambitnej turystki. Zamiast zapytać o drogę, chętnie płaci cenę błądzenia po stolicy NRD, a ostatecznie zaczyna zwiedzać ją bez pomocy mapy ${ }^{45}$. Tramwaj i autobus to dla Gröschner wehikuły czasu, pojazdy transgraniczne, którymi podróżuje po mieście, wracając do dawnych epok wciąż obecnych w stylach architektonicznych i w jego wizualnej szacie. Swoje pierwsze doświadczenie z podróży w czasie po Berlinie tramwajem linii 70 autorka relacjonuje następująco:

W pewnym momencie kamienice $\mathrm{z}$ okresu grynderskiego (Gründerzeithäuser) i osiedla socjalne $\mathrm{z}$ lat dwudziestych i pięćdziesiątych ustąpiły miejsca rozciągającym się na dużej powierzchni ogródkom działkowym. Przejeżdżałam obok podziurawionej pociskami wieży ciśnień, tramwaj z trudem przedzierał się przez jakąś wiejską uliczkę, skręcił obok kościoła i zatrzymał się przed zniszczonym domem, którego tynk musiał niedawno odpaść dużymi płatami. [...] Przystanek dalej trasa się kończyła. Nie było niczego, co pozwoliłoby mi się tu zatrzymać, ale przynajmniej wiedziałam, jak wyglądał Heinersdorf. Wtedy jeździły jeszcze stare tramwaje z Gothy, które piszczały na zakrętach. I były też szyny w płytach chodnikowych, po których od dawna nie jeździły żadne tramwaje. Na Wollankstraße szyny biegły pod murem i zakładałam, że prowadziły jeszcze dalej, do Wedding, który na mapie Berlina Wschodniego zaznaczono białą plamą. Silniej niż biała wstęga muru fascynowały mnie te zapomniane szyny. To były pęknięcia w środku miasta, którego wschodnia część jeszcze w 1983 roku nosiła widoczne ślady wojny ${ }^{46}$.

\footnotetext{
43 Tamże, s. 14.

${ }_{44}$ Tamże.

45 Tamże, s. 12.

${ }^{46}$ Tamże.
} 
Mur berliński jest dla pisarki symbolem zamknięcia, zniewolenia i ograniczenia wolności, ale również przeszkodą w przemieszczaniu się po Berlinie. Granica między wschodem a zachodem oznacza dla Gröschner koniec podróży liniami tramwajowymi, które nie znikają przed betonowymi płytami muru, lecz ciągną się pod nim i są łącznikiem ze światem, do którego pisarka nie ma wstępu. Podział na wschód i zachód to w utworze Gröschner przymus opuszczenia wagonu tramwajowego po wschodniej stronie miasta i bodziec do snucia wyobrażeń na temat legendarnego Berlina Zachodniego, wizualizowanego przez kartografów NRD jako biała plama $^{47}$, którą pisarka konfrontuje z rzeczywistością dopiero po upadku muru. Nie „biała wstęga muru” na mapie Berlina, ale zapomniane szyny tramwajowe są dla tej turystki-we-własnym-mieście najdotkliwszym doświadczeniem podziału miasta.

\section{Szóstką po dzielnicy Mitte}

W eseju osadzonym na trasie linii tramwajowej nr 6 historię Berlina piszą rozmaite miejskie artefakty: znikające i powstające budynki, przebudowane ulice i place, zamykane lokale, kina i centra handlowe. Mijając pole golfowe przy Chaussestraße, tramwaj pokonuje w oczach narratorki granicę między ruiną a dobrobytem ${ }^{48}$. Pole golfowe i biurowce - „szklane pałace" 49 - kontrastują z szyldami upadłych sklepów i ruiną z oknami zabitymi tekturą. Zaledwie nielicznym obiektom przy Chaussestraße udało się dotrwać do współczesności. Przykładem jest najstarszy w Berlinie Pałac Tańca, wybudowany w 1905 roku pod numerem 102, do 2014 roku znany jako „Deutsches Ballhaus”. Przetrwał wojnę, zmiany ustroju politycznego i mody muzyczne. Śledząc najnowszą historię obiektu, znalazłam informację o jego sprzedaży i gruntownej renowacji w 2014 roku $^{50}$. Nowi właściciele - Christoph Blaesius i Karl-Heinz Heymann - postawili na połączenie tradycji z nowoczesnością. W blisko 110-letnim budynku o nowej nazwie „Ballhaus Berlin” złocona sztukateria i telefony przy numerowanych stołach stanowią stałe tło dla współczesnego kalendarium imprez łączących dawne (swing) i nowoczesne (techno) ${ }^{51}$. Kolejnym re-

\footnotetext{
47 Tamże, s. 54.

48 Tamże, s. 183.

49 Tamże.

50 S. Grothe, Techno am Tischtelefon, <http://www.tagesspiegel.de/berlin/ballhausberlin-wieder-geoeffnet-techno-am-tischtelefon/9735590.html>, dostęp: 15.07.2014.

51 Tamże.
} 
kwizytem minionej epoki przy tej ulicy jest dla autorki sklep z numizmatami - „Moneta”52.

Historię niewidzialnego miasta na trasie tramwajowej „szóstki” współtworzy nieistniejący Palasthotel nad Szprewą, wybudowany w 1976 roku dla gości dewizowych. Narratorka informuje, że została po nim jedynie wielka dziura ${ }^{53}$. Czytelnik $\mathrm{z}$ łatwością zbada, że $\mathrm{w}$ tym miejscu mieści się obecnie budynek City Quartier, a w nim powstały w 2004 roku hotel sieci Radisson Blue oraz DomAquée.

Kolejnym przykładem palimpsestowej struktury tkanki miejskiej Berlina jest położony na trasie „szóstki” Alexanderplatz z kinem UfaPalast, którego zmierzch proroczo zapowiedziała pisarka54. Kino Ufa-Palast najpierw stanęło w miejscu dawnej dyskoteki „Alextreff” na Rathausstraße, zaś w 2001 roku ustąpiło miejsca nowoczesnemu kompleksowi „Cubix Ufa-Palast”55. Budynek dawnej dyskoteki zajmowali przed wyburzeniem bezdomni, którzy także dziś, obok kobiet pospiesznie robiących zakupy w drodze z pracy do domu, są stałym elementem krajobrazu społecznego na Alexanderplatz ${ }^{56}$.

Niektóre miejsca na trasie „szóstki” zniknęły bezpowrotnie z planu miasta, inne odrodziły się w nowej odsłonie, jak wspomniany Ballhaus Berlin, lub zmieniły swoją funkcję, jak wieżowiec na Alexanderplatz Haus des Lehrers (Dom Nauczyciela), który od 2001 roku należy do spółdzielni mieszkaniowej Berlin-Mitte. W AlexTreff już się nie tańczy jak za czasów NRD, za to w nowym Alex-Treff na Rosa-Luxemburg-Straße zorganizowano czytelnię. Pracownica centrum kulturalnego Alex-Treff wyjaśniła mi w mailu, że zbieżność nazwy dawnej dyskoteki i dzisiejszej czytelni jest przypadkowa i że „...tu, na Alexanderplatz, zbieżność nazw jest częsta i dochodzi do pomyłek" 57 . Treść maila traktuję jako potwierdzenie hybrydycznej struktury placu.

Narratorka z nostalgią wspomina typowe dla socjalistycznej zabudowy osiedlowe punkty usługowe $\mathrm{z}$ rynkiem warzywnym (Dienstleistungs-

52 Latem 2014 roku, kiedy powstawał ten artykuł, znalazłam informację o istnieniu przy Oranienburger Straße spółki handlowej Moneta: <http://firma-24.de/moneta-beteiligungsges-mbh-oranienburger-stra\%C3\%9Fe-berlin>, dostęp: 15.07.2014. Odnaleziony bezproblemowo, wydaje się stałym punktem w zmieniającym się krajobrazie ulicy po przełomie.

${ }^{53}$ A. Gröschner, Hier beginnt die Zukunft..., s. 185.

54 Tamże, s. 185.

55 U. Aulich, Ein Zeichen für den Aufbruch am Alex, <http://www.berliner-zeitung. de/archiv/ufa-eroeffnet-neues-kino---2002-beginnt-der-umbau-der-rathauspassagen--ein-ze ichen-fuer-den-aufbruch-am-alex-,10810590,9942114.html>, dostęp: 15.07.2014.

${ }_{56}$ Por. A. Gröschner, Hier beginnt die Zukunft..., s. 185.

57 Prywatna korespondencja z Sabine Burgaleta, z 18.07.2014. 
würfel) na odcinku trasy w kierunku dzielnicy Marzahn ${ }^{58}$. Przegrały one walkę o przetrwanie z przeszklonymi pasażami handlowymi. Komercja wyparła tradycję z przestrzeni miejskiej.

\section{Berlin Zachodni}

Oczywistą konsekwencją upadku muru berlińskiego są także zmiany w zachodniej części Berlina, które Gröschner diagnozuje, podróżując między innymi autobusem linii 129. Symbolem rewolucji przestrzennej $\mathrm{w}$ Berlinie lat dziewięćdziesiątych jest np. koniec świetności dawnej reprezentacyjnej ulicy Kurfürstendamm, w skrócie Ku'damm, w dzielnicy Charlottenburg, która przyciągała berlińczyków i turystów ekskluzywnymi butikami, domami towarowymi, licznymi kawiarenkami i małymi kinami. Większość z nich dziś już nie istnieje. Autorka podaje przykład upadku legendarnej kawiarni Café Kranzler po 175 latach działalności oraz narodziny jej ponowoczesnego klonu - Neues Kranzler Eck. W budynku dawnej kawiarni mieści się teraz sklep z odzieżą House of Gerry Weber. Gröschner przywołuje w tym kontekście wypowiedź Hessela, który już w 1928 roku orzekał: „Stary Zachód stracił, jak mawia się o rzeczach pięknych, które wychodzą z mody”59.

\section{Hessel, Gröschner i Märchentante}

Tom esejów miejskich kończą zapiski z wycieczki autobusem szlakiem atrakcji turystycznych Berlina (Stadtrundfahrt). W tej miniaturze autorka sięga po literackie obrazy Berlina ze Spazieren in Berlin ${ }^{60}$ Hessela i tworzy collage narracyjny, łącząc wizję przewodniczki z impresją Hessela i własnym komentarzem. Hessel jest tu synonimem pamięci totalnej Berlina lat dwudziestych, autorytetem rozstrzygającym o istnieniu elementów zabudowy architektonicznej na planie miasta, a także zbieżności na mapie linii autobusów i tramwajów z lat dwudziestych oraz na przełomie XX i XXI wieku. Pomimo drugiej wojny światowej i podziału Niemiec ulica Unter den Linden jest dla pisarki synonimem niezmienności i ciągłości historii miasta. Na przystanku autobusu wycieczkowego

58 W Poznaniu takie obiekty usługowe przetrwały przełom 1989 roku i nieprzerwanie działają np. na os. Wichrowe Wzgórza, czy przy ul. Świt.

59 A. Gröschner, Hier beginnt die Zukunft..., s. 165.

60 F. Hessel, Spazieren in Berlin. Neuausgabe von Spazieren in Berlin; Hrsg. und mit einem Nachwort von P. Moses-Krause. Mit Fotografien von F. Seidenstücker, Berlin 2011. 
o nazwie „Hotel Unter den Linden”61 współczesność wyparła przeszłość: zamiast boya hotelowego $\mathrm{w}$ liberii stoi tam rdzenny berlińczyk w szortach, sprzedawca ticketów - nie biletów - na zwiedzanie miasta z oryginalnym komentarzem ${ }^{62}$. Od narratorki dowiadujemy się, że przewodniczka $\mathrm{z}$ autobusu turystycznego przedstawia się turystom $\mathrm{w}$ berlińskim dialekcie jako „Märchentante” (bajarka). Na wcześniejszej wycieczce objazdowej po Berlinie Gröschner usłyszała w audioprzewodniku historię Berlina, którą mogła „włożyć między bajki”. Luki w przekazie historii miasta czyniły je przestrzenią wyobrażoną, niemal legendą. Autorka następująco wspomina tę sytuację:

Tekst miał przynajmniej rok. Zaproszenie na kawę do kawiarni Kranzler zderzyło się z rzeczywistością budynku w remoncie, w którym jeszcze do niedawna znajdowała się kawiarnia Kranzler. Głos na taśmie przeskoczył ten odcinek trasy z historią muru berlińskiego. Włosi przede mną rozglądali się, szukając muru. Prawdopodobnie wyjechali do domu z wyobrażeniem, że mur berliński znajdował się na Stuttgarter Platz ${ }^{63}$.

Gröschner warstwa po warstwie odsłania historię Wilhelmstraße, ważnej arterii Prus, Republiki Weimarskiej i Trzeciej Rzeszy. Powraca historia Nowej Kancelarii Rzeszy (Neue Reichskanzlei), centrum dowodzenia Hitlera, zniszczonego podczas wojny i wyburzonego ostatecznie przez sowiecką komisję kontrolną w 1954 roku. Pisarka przy okazji „oprowadzania” czytelnika po współczesnym i niewidzialnym mieście, daje mu lekcję krajoznawstwa, przypominając o zastąpieniu we wschodnioniemieckiej nomenklaturze jednoznacznie negatywnie konotowanego słowa: „Führer” (wódz, przewodnik) w „Stadtführer” przez leksem Erklärer” w „Stadterklärer” (objaśniający miasto). W przewodniku Gröschner można znaleźć również stricte lokalne nazwy wybranych, ważnych dla tożsamości berlińczyków obiektów, jak w przypadku budynku urzędu kanclerza, który ze względu na pokaźne okno w fasadzie głównego gmachu nosi nazwę „Oko kanclerza”64.

$\mathrm{Na}$ trasie wycieczkowego autobusu po stolicy Niemiec nie mogło zabraknąć także dworca „Berlin ZOO”, zbudowanego z okazji olimpiady w 1936 roku, i ruin Kościoła Pamięci „Kaiser-Wilhelm-Gedächtniskirche”, znanego berlińczykom jako „spróchniały ząb” (Hohler Zahn) ${ }^{65}$, projektu architekta Franza Schwechta - budowniczego zamku cesarskiego w Poznaniu.

\footnotetext{
61 Najprawdopodobniej chodzi tu o legendarny luksusowy hotel „Adlon”.

${ }^{62}$ A. Gröschner, Hier beginnt die Zukunft..., s. 206.

63 Tamże, s. 206.

64 Tamże, s. 208.

65 Tamże, s. 209.
} 
Kolejnym przystankiem w podróży narratorki w czasie i przestrzeni jest plac Poczdamski. Literacki obraz tego miejsca także stanowi wypadkową opowieści przewodniczki z turystycznego autobusu i komentarzy narratorki, która łączy własne wspomnienia z impresjami Hessela. Ten poetycki portret placu zdominowało wspomnienie kompleksu architektonicznego Haus Vaterland (Dom Ojczyźniany), mieszczącego przed wojną kino, kawiarnie, restauracje i teatr na wolnym powietrzu - dla Hessela symbolu zbliżającego się reżimu, od którego uciekł w 1937 roku. Plac Poczdamski w kolażowej narracji Gröschner jawi się jako suma pamięci o jednym z najruchliwszych i najnowocześniejszych placów Europy lat dwudziestych oraz o przestrzeni niczyjej, architektonicznie uśpionej przez blisko 50 lat i rozpiętej między wschodnią i zachodnią częścią Berlina. Dzisiejszy plac Poczdamski jest symbolem boomu budowlanego lat dziewięćdziesiątych i przykładem nowoczesnej zabudowy architektonicznej miasta, a jednocześnie wizualizacją perfekcyjnego zatarcia przeszłości. Plac Poczdamski, niegdyś podzielony murem, nie przypomina dziś, z wyjątkiem dwóch obiektów zintegrowanych z postmodernistyczną architekturą, tej przestrzeni sprzed roku 1945 i z czasów zimnej wojny. Weinhaus Huth z 1912 roku (Winiarnia Huth) pełni dziś funkcję restauracji, a pozostałości po hotelu Esplanade wkomponowano w budynek siedziby Sony Center. Plac Poczdamski jest przykładem przezwyciężenia podziału Wschód-Zachód w kontekście historii do 1989 roku. Gröschner zauważa:

Najciekawszy był plac Poczdamski w połowie lat dziewięćdziesiątych, kiedy koparki wżarły się w ziemię i odkryły wymarły świat, piwnice „Pschorbräuhauses”66, piwnice „Haus Vaterland” i piwnice "Café Josty” obok starych linii tramwajowych i krawężnika. Wszystko to jest teraz zabudowane, a zdanie Renzo Piano: „Stopami w przeszłość, głową w przyszłość” nie dotyczy już placu, gdyż jego przeszłość jest tu całkowicie zatarta, jak gdyby nigdy żadnej nie miał ${ }^{67}$.

Gröschner, podobnie jak Hessel siedemdziesiąt lat wcześniej, podkreśla tymczasowość przestrzeni placu, który dopiero po upadku muru i metamorfozie architektonicznej staje się „tym właściwym”68. U grupy turystek wycieczkowego autobusu, nieświadomych topografii Berlina i celowości trasy wycieczki wzdłuż zachowanych fragmentów muru, widok jego fragmentu na Stresemannstraße i w pobliżu Martin-Gropius-Bau ${ }^{69}$, a także bliskość muzeum muru berlińskiego „Checkpoint Charlie”

66 Pschorr to nazwa bawarskiego browaru.

67 G. Gröschner, Hier beginnt die Zukunft..., s. 210-211.

68 Tamże, s. 211.

69 W latach 1877-1881 budynek był siedzibą Muzeum Rzemiosła Artystycznego, natomiast współcześnie pełni funkcję obiektu wystawowego. 
nie wywołują żadnej refleksji nad przeszłością podzielonych Niemiec ${ }^{70}$. Narratorka pełni w tym eseju rolę komentatorki i recenzentki przewodniczki. Przypomina o modernistycznej zabudowie Alexanderplatz, o znajdującej się tam restauracji „Ahornblatt” - symbolu modernistycznej architektury NRD. Zauważa także, że kwartał św. Mikołaja (Nikolaiviertel) różni się od tego, który Hessel opisał w Spazieren in Berlin. Wąskie uliczki, po których jeździł niegdyś pisarz, zastąpił deptak, a po rewitalizacji z 1987 roku z okazji 750-lecia powstania miasta dzielnica stała się atrakcją turystyczną, niczym „Disneyland”71.

Komentarze narratorki ożywiają zapomnianą historię ulic, budynków, pomników i rzeźb. Wspomnieć tu należy o takich obiektach z początku XX wieku, jak Altes Stadthaus (Stary Ratusz) architekta Ludwiga Hoffmanna i statui niedźwiedzia, symbolu miasta, wykonanej w 1910 roku z brązu przez Georga Wrbę. Egzemplifikują one przeszłość obecną $\mathrm{w}$ historycznej przestrzeni miasta i przemiany polityczne $\mathrm{w}$ Berlinie w XX wieku ${ }^{72}$.

Uprzestrzennienie historii i burzliwej przeszłości Berlina pisarkanarratorka prezentuje również na przykładzie zmiany lokalizacji fontanny Neptuna, niegdyś zdobiącej plac przed zniszczonym podczas wojny zamkiem Hohenzollernów ${ }^{73}$, który ostatecznie ustąpił miejsca pałacowi

${ }^{70}$ Wydaje się w tym kontekście, że eseje Gröschner dobrze spełniają funkcję memuaru i bedekera i w związku z tym przeznaczone są dla dwóch typów odbiorców. Czytelnik świadomy przeszłości miasta będzie mógł dzięki zawartym w nich informacjach odnieść się do swojej wiedzy, a także do pamięci indywidualnej i skonfrontować własne obrazy miasta z jego literacką reprezentacją. Niezorientowanemu zaś czytelnikowi, dla którego niezrozumiałe są przytoczone przez autorkę-narratorkę nazwy nieistniejących już obiektów czy ulic, mogą stać się impulsem dla wykształcenia wyobraźni przestrzennej i posłużyć jako przewodnik po niewidzialnym mieście oraz zachęcić do własnych badań i odkrywania realnej przestrzeni współczesnego Berlina.

${ }^{71}$ A. Gröschner, Hier beginnt die Zukunft..., s. 212.

72 Gröschner przywołuje dwa przykłady symbolicznych aktów ideologizacji przestrzeni miejskiej i jej artefaktów. Chodzi o przeniesienie posągu niedźwiedzia z tzw. Sali Niedźwiedziej Starego Ratusza (Altes Stadthaus) w latach 50., kiedy to budynek stał się siedzibą rady ministrów NRD, na plac zabaw do powstałego w r. 1955 ogrodu zoologicznego w Friedrichsfelde, jak i o jego powrót do Starego Ratusza w 2001 roku. Przeniesienie należy odczytać jako odcięcie się od pruskiej tradycji w duchu mitu założycielskiego NRD, a powrót do ratusza - jako symboliczne nawiązanie do historii wspólnej dla obu społeczeństw: wschodnio- i zachodnioniemieckiego - więc tej sprzed II wojny światowej i podziału Niemiec, oraz odwołanie się do pamięci kulturowej i zbiorowej berlińczyków. Oryginał statuy niedźwiedzia trafił na swoje pierwotne miejsce przeznaczenia, zaś jego kopia stoi dziś w Tierpark Berlin (berliński Ogród Zoologiczny, w dawnym Tierpark Friedrichsfelde).

${ }^{73}$ Ostatecznie po kilkuletnim sporze o znaczenie zamku dla tożsamości miasta i jego mieszkańców rozpoczęto w 2013 jego odbudowę w miejscu wyburzonego Pałacu Republiki. Obiekt ma być ukończony w 2019 roku. 
Republiki, siedzibie parlamentu NRD ${ }^{74}$. Przewodniczka turystyczna nazywa go żartobliwie „balastem Republiki”"5, nawiązując do rakotwórczego azbestu, którym nasycony był budynek parlamentu.

Kolejną atrakcją turystyczną na trasie wycieczkowego autobusu jest most Zamkowy (Schlossbrücke), który w latach 1951-1991 utracił swoją wilhelmiańską przeszłość i zafunkcjonował pod nazwą mostu Marksa i Engelsa (Marx-Engels-Brücke). Zdobiące go rzeźby - postaci z mitologii greckiej - ukryte na czas wojny w zachodniej części miasta, odrestaurowane wróciły na właściwe miejsce w 1983 roku.

Wielokrotnie semantyzowanym obiektem-kameleonem, swoistą architekturą pamięci o minionych epokach i ustrojach, staje się Kronprinzessinnenpalais (pałac Następczyń Tronu). Obiekt ten przed II wojną światową dwukrotnie zmieniał przeznaczenie, w jej trakcie uległ całkowitemu zniszczeniu, w r. 1968 został odbudowany jako Gästehaus der Stadt (rodzaj hotelu miejskiego). Po przełomie 1989 roku odzyskał swoją starą nazwę i, odrestaurowany, służy współcześnie jako miejsce wystaw i przedstawień teatralnych.

Także turyści odpoczywający na schodach Nowego Odwachu (Neue Wache) zaprojektowanego przez Karla Friedricha Schinkla, skłaniają pisarkę do spojrzenia w przeszłość i odsłonięcia palimpsestowego charakteru tego obiektu. Wraz z końcem epok i przełomami politycznymi zmieniało się bowiem jego przeznaczenie ${ }^{76}$.

Ostatnią atrakcją turystyczną wycieczki po dzielnicy Mitte jest w utworze Gröschner puste miejsce po pomniku Fryderyka Wielkiego, który w 1950 władze NRD przeniosły „za pruskość” z Berlina do Poczda$\mathrm{mu}$, a po zrewidowaniu historii pod koniec lat osiemdziesiątych przywróciły na ulicę Unter den Linden.

\section{Więcej niż dziennik}

Przykładów miejsc, budynków i nazw ulic przywołanych mapą linii komunikacji miejskiej Berlina i odkrywających palimpsestowy charakter miasta jest w tekstach Gröschner bardzo wiele. W rezultacie zbiór esejów miejskich Hier beginnt die Zukunft, wykorzystujący literacko-historyczną

${ }^{74}$ Po wojnie, w 1969 roku fontanna stanęła pomiędzy Czerwonym Ratuszem i Wieżą Telewizyjną.

${ }^{75}$ A. Gröschner, Hier beginnt die Zukunft..., s. 212.

${ }^{76}$ Wartownia powstała dla artylerzystów Fryderyka Wilhelma III, a po abdykacji króla służyła jako pomnik na cześć poległych w I wojnie światowej. W czasach NRD pomnik poświęcono pamięci ofiar faszyzmu i militaryzmu, a od r. 1993 - wszystkim ofiarom wojny i tyranii. 
narrację osadzoną na autentycznym planie miasta i mapie sieci komunikacyjnej, pozwala uchwycić wielowarstwowy i historyczny pejzaż miejski współczesnej stolicy Niemiec. Narratorka pełni w utworach funkcję flaneura, subiektywnego obserwatora i komentatora zmian w przestrzeni miejskiej Berlina przed 1989 rokiem i po upadku muru berlińskiego. Tomik czyta się niczym bardzo gęsto zapisaną faktami historycznymi kronikę miasta, czasem jak podręcznik historii, czasem jak alternatywny przewodnik po mieście, w którym niemal każda ulica, każdy przystanek na trasie tramwaju czy autobusu otrzymują rzetelny przypis i zyskują historyczną głębię. Przejażdżka środkiem komunikacji miejskiej i spacer po Berlinie okazują się podróżą w czasie, zbliżeniem do przeszłości ukrytej pod płytami chodnika i za tynkami wyremontowanych budynków czy nowych obiektów. Twórczość Gröschner jest schodzeniem w głąb miasta i jego historii, zapisanej w kolejnych warstwach czasu, Koselleckowych „Zeitschichten”, a nade wszystko - pomostem między przeszłością i teraźniejszością. Jeśli jednak uwzględnić obserwację Gröschner, poczynioną podczas odkrywania Berlina autobusem linii 257, jej eseje miejskie nabierają nowego znaczenia:

Galeria Lafayette na rogu Friedrichstraße daje o sobie znać wielkimi literami: TU ZACZYNA SIĘ PRZYSZŁOŚĆ. Od czasu do czasu przyszłość przechodniów jest jednak zagrożona spadającymi fragmentami szklanej fasady, które rozbijają się na chodniku na tysiące małych kawałków. Na tablicach informujących o budowie zapowiedziano wielki boom, na chodnikach namalowano damy w kapeluszach i mężczyzn w garniturach, przyszłych klientów. [...] Jeśli chce się poczuć samotność w środku miasta, powinno się jechać na Friedrichstraße i przespacerować pomiędzy Quartier 205 i Quartier 207. W oknach szyb odnajdzie się tylko siebie samego ${ }^{77}$.

W Pasażach Benjamina nowa galeria handlowa zastąpiła kupieckie pasaże, skłaniając teoretyka kultury do refleksji nad przeszłością XIX-wiecznej Francji. Nowoczesna konstrukcja architektoniczna - galeria Lafayette - materializująca przyszłość zorientowaną na modernizację i konsumpcję, wywołuje w autorce krytyczny dystans i potrzebę opowiedzenia historii Berlina, który na skutek radykalnej przebudowy w zastraszającym tempie staje się miastem-widmem. Drugi człon tytułu tomu esejów Gröschner: „hier steigen wir aus” (tu wysiadamy) oznajmia koniec podróży i wyraża symboliczny sprzeciw wobec zmian w przestrzeni miasta, wobec „wymazywania” z niej niedawnej historii. W szybie galerii, która jako nie-miejsce nie odbija historycznej przeszłości, przegląda się

77 A. Gröschner, Hier beginnt die Zukunft..., s. 26. 
przechodzień-konsument ${ }^{78}$. Omawiany w niniejszym artykule tomik esejów miejskich Gröschner jest czymś więcej niż subiektywnym dziennikiem, dokumentującym dekontaminację przeszłości z przestrzeni miejskiej Berlina i sukcesywne zastępowanie jej przestrzenią konsumpcji. Jest on literacką relacją sporu między homo conservator i homo investor $^{79}$, jaki rozegrał się w młodej stolicy zjednoczonych Niemiec po przełomie 1989/1990 roku, i który trwa do dziś.

\section{LITERATURA}

Assmann A., Geschichte findet Stadt, [w:] Kommunikation - Gedächtnis - Raum. Kulturwissenschaften nach dem »Spatial Turn«, red. M. Csăky, Ch. Leitgeb, Bielefeld 2009, s. 13-27.

Assmann A., Geschichte im Gedächtnis. Von der individuellen Erfahrung zur öffentlichen Inszenierung, München 2007.

Augè A., Nie-miejsca. Wprowadzenie do antropologii hipernowoczesności, Warszawa 2010.

Benjamin W., Ausgraben und Erinnern, [w:] Gesammelte Schriften, IV. 1, red. T. Rexroth, Frankfurt am Main 1972.

Benjamin W., Berliner Chronik, [w:] Walter Benjamin - Gesammelte Schriften, Bd. VI: Fragmente, Autobiographische Schriften, red. R. Schweppenhäuser, W. Tiedemann, Frankfurt am Main 1984.

Benjamin W., O pojęciu historii, [w:] tegoż, Anioł historii. Eseje, szkice, fragmenty. Wybór i oprac. H. Orłowski, przeł. K. Krzemieniowa, H. Orłowski, J. Sikorski, Poznańska Biblioteka Niemiecka, t. 2., Poznań 1996.

Benjamin W., Passagenwerk, [w:] Walter Benjamin, Gesammelte Schriften, Bd. V. 2, red. R. Tiedemann, Frankfurt am Main 1982.

Berking H., Löw M. [red.], Die Eigenlogik der Städte. Neue Wege für die Stadtforschung, Frankfurt am Main 2008.

Csăky M., Leitgeb Ch. [red.], Kommunikation - Gedächtnis - Raum. Kulturwissenschaften nach dem »Spatial Turn«, Bielefeld 2009.

Gröschner A., Heimatkunde Berlin, Hamburg 2010.

Gröschner A., Hier beginnt die Zukunft, hier steigen wir aus. Unterwegs in der Berliner Verkehrsgesellschaft, Berlin 2002.

Gröschner A., Parzelle Paradies, Hamburg 2008.

Kalaga W. [red.], Dylematy wielokulturowości, Kraków 2004.

78 Gröschner w przytoczonym cytacie niemal parafrazuje Marca Augé w kontekście samotności konsumenta w nie-miejscu: Przestrzeń nie-miejsca nie tworzy ani szczególnej tożsamości ani relacji, lecz samotność i podobieństwo". M. Augè, Nie-miejsca. Wprowadzenie do antropologii hipernowoczesności, przeł. R. Chymkowski, Warszawa 2010, s. 71.

${ }^{79}$ A. Assmann, Geschichte im Gedächtnis..., s. 117. 
Kusiak J., Walter Benjamin i metodologia antropologicznego materializmu. Krzesanie dialektycznych iskier na metalowej głowie Ernsta Thälmanna, „Praktyka Teoretyczna" 2013, nr 2(8), s. 309-332.

Ledanff S., Metropolisierung der deutschen Literatur? Welche Möglichkeiten eröffnet das vereinigte Berlin und die Berliner Urbanität?, [w:] Schreiben nach der Wende. Ein Jahrzehnt deutscher Literatur 1989-1999, red. G. Fischer, D. Roberts, Tübingen 2001.

Lindner R., Textur, imaginaire. Habitus - Schlüsselbegriffe der kulturanalytischen Stadtforschung, [w:] Die Eigenlogik der Städte. Neue Wege für die Stadtforschung, red. H. Berking, M. Löw, Frankfurt am Main 2008, s. 83-94.

Popczyk M., Berlin - miasto widzialnej nieobecności, [w:] Dylematy wielokulturowości, red. W. Kalaga, Kraków 2004, s. 239-261.

Rewers E., Post-polis. Wstęp do filozofii ponowoczesnego miasta, Kraków 2005.

Rybicka E., Geopoetyka. Przestrzeń i miejsce we wspótczesnych teoriach i praktykach literackich, Kraków 2014.

Schlögel K., W przestrzeni czas czytamy. O historii cywilizacji i geopolityce, Poznań 2009.

\section{ŹRÓDŁA INTERNETOWE}

Aulich U., Ein Zeichen für den Aufbruch am Alex. <http://www.berliner-zeitung.de /archiv/ufa-eroeffnet-neues-kino---2002-beginnt-der-umbau-der-rathauspassagen --ein-zeichen-fuer-den-aufbruch-am-alex-,10810590,9942114.html>, dostęp: 15.07. 2014.

<www.bvg.de/index.php/de/3746/name/MetroTramlinie+M13.html>, dostęp: 4.08. 2014.

Grothe S., Techno am Tischtelefon. <http://www.tagesspiegel.de/berlin/ballhaus-ber lin-wieder-geoeffnet-techno-am-tischtelefon/9735590.html>, dostęp: 15.07.2014. 
